\title{
In memoriam Peter deLeon
}

\section{Hellmut Wollmann}

\section{(2) OpenEdition}

\section{Journals}

Electronic version

URL: http://journals.openedition.org/irpp/1232

DOI: 10.4000/irpp.1232

ISSN: 2706-6274

\section{Publisher}

International Public Policy Association

\section{Printed version}

Date of publication: 1 September 2020

Number of pages: 138-140

ISSN: 2679-3873

\section{Electronic reference}

Hellmut Wollmann, "In memoriam Peter deLeon", International Review of Public Policy [Online], 2:2 I

2020, Online since 01 September 2020, connection on 29 January 2021. URL: http://

journals.openedition.org/irpp/1232 ; DOI: https://doi.org/10.4000/irpp.1232

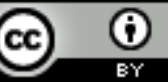

International Review of Public Policy is licensed under a Creative Commons Attribution 4.0 International. 


\section{In memoriam Peter deLeon}

\section{Hellmut Wollmann}

Emeritus, Humboldt University, Berlin

In commemorating Peter deLeon and in paying homage to him as a brilliant scholar, great human being and good friend, I wish, in this brief note, to thankfully recall and acknowledge the cordial encounters with him, the insights and inspirations he gave me as well as the valuable contribution he made to the field of public policy research and policy sciences worldwide, not least in Germany.

I met Peter de Leon while he was in Germany on several occasions during the 1980s. Our communication and interaction intensified when he got involved in an international research network which, initiated and coordinated by Peter Wagner, Björn Wittrock and myself, was formed in the late 1980s at the Science Centre Berlin (Wissenschaftszentrum Berlin). Guided by a common interest in the "history of science" and "sociology of knowledge", the research consortium aimed at exploring the development of applied social science from an international comparison angle. The group comprised, among other eminent scholars in the field, Carol Weiss, Martin Rein, Martin Bulmer and, last but not least, Peter deLeon. The collective undertaking resulted in a volume entitled "Social Sciences and Modern States" that was co-edited by Peter Wagner, Carole Weiss, Björn Wittrock and myself and was published in 1991 by Cambridge University Press. Peter wrote a valuable chapter entitled "political events and policy sciences" in which he analysed, in line with the common "history of science" track, the emergence and phases of policy research, including the development of "policy sciences", essentially tracing back to the seminal volume published by Harold Lasswell and David Lerner in 1951 under the programmatic title "policy sciences". Peter's profound erudition grounded in the Lasswellian tradition and enriched by his work at the RAND Corporation, as well as his amicable and communicative personal style, contributed greatly to the lively and productive discussions in the international community and bore splendid fruit in his chapter in the collective volume.

The interest that Peter de Leon and I shared in the comparative study of the "history of science" and "history of the discipline" drew our attention to the intriguing example and phenomenon of a mutual fertilisation that occurred, in a temporally "staggered" and historically phased way, between the German and US American social science communities, hinting at a peculiar "special linkage" between them over time. This seems worth spelling out a little further in this brief commemorative note.

In Germany, the emergence of historical and comparative research in academic teaching and investigation in public affairs and policies dates back to the $18^{\text {th }}$ century, when the Prussian king established professorships in so-called Cameralism (Kameralwissenschaften) at the newly created universities in 1723 in Halle and Frankfurt/Oder. The aim was to educate and train a new breed of public administrators and, for this purpose, to draw comprehensively on the then available (still elementary) administrative, economic technical etc. knowledge deemed relevant for running the (mercantilist) State. Another contemporary label of this emergent academic track was Policeywissenschaften which, as the term "Policey" at the time, denoting "public policy 
matters" at large, may be translated, nota bene, as "policy science". Small wonder that the Kameralwissensschaften, as well as the Policeywissenschaften, have, not least because of their "quasi -interdisciplinary" and "applied" orientation, sometimes been identified as an early version and forerunner of today's "policy sciences". From this, in the further course of the $19^{\text {th }}$ century, the concept of Staatswissenschaften (sciences of the State) evolved, for which new professorships ("chairs") were established at the universities of Berlin and Leipzig. A leading protagonist was Lorenz von Stein who, drawing on the notion of the "working state" (arbeitender Staat), conceived Staatswissenchaften as an "integrative" science which combines legal, economic and social science knowledge for practical purposes. Further, around the 1860s, gathering around the Association of Social Policy (Verein für Socialpolitik), a group of reform-minded historian-economists, among whom Gustav Schmoller stood out, initiated and conducted empirical research on the (dismal) living, especially housing, conditions of the working class. As they explicitly targeted their empirical research at calling for and at underpinning social policy reforms, they came to be nicknamed "lectern socialists" (Kathedersozialisten).

Against this historical background, between the mid- $19^{\text {th }}$ and the end of the $19^{\text {th }}$ century, a great number of US American students came to study at German universities, which at the time enjoyed an esteemed international reputation and attraction for the quality of academic teaching and research based on the Humboldtian principle of the "unity of teaching and research". When returning to the US, many of them, such as, for instance, Albion Woodbury Small and Charles E. Merriam, embarked upon academic careers and went on to play a leading role in shaping the emergent academic landscape in the US. Thus, it can plausibly be assumed that the acquaintance this cohort of US American students made at German universities with Staatswissenschaften and with applied social policy research entailed a "knowledge transfer" and "travel" that bore fruit in the burgeoning academic scene in the US.

After 1945, following the liberation from the Nazi regime, in (West) Germany the build-up of university teaching and research in sociology and political science was decisively influenced by a massive "knowledge transfer" from the US. This was transmitted significantly by German scholars who were, under the Nazi regime, forced to leave the country and then began or continued their academic career in the US. When returning to Germany after 1945, they played a key role in the country's academic revival, scholars such as Carl Joachim Friedrich, Ernst Fraenkel, Richard Löwenthal, Sigmund Neumann, Fritz Morstein-Marx, to name but a few.

I myself spent a year, in 1957/58, as a Fulbright exchange student at Wesleyan University, Conn, and another year, in 1970/71, as Kennedy Memorial Fellow at Harvard. In the social science and political science research that has unfolded since the 1950s, the subject matters, approaches and concepts have considerably drawn on and reflected phases and currents in the US academic development, which Peter de Leon aptly identified and explained in his contribution to the afore-mentioned collective volume. This applies, not least, to implementation research as pioneered by Aaron Wildavsky, to evaluation research as promoted by Carol Weiss or to public policy research, which received pivotal clues from the "policy sciences" as designed and promulgated by Harold Lasswell and David Lerner in 1951.

In the "history of science" and a comparative perspective, it can plausibly be argued that, particularly with regard to its key concepts of interdisciplinarity and application orientation, "policy science" has peculiarly "travelled" well over time between the German and the US American social science communities. After emerging, in an early format, in $19^{\text {th }}$ century Germany's Policeywissenschaften and Staatswissenschaften and making its way, via cohorts of US American students, into the emergent US academic world, it thence returned in the elaborate and pro- 
grammatic stance of the Lasswellian "policy sciences" to the European, particularly German shores, to advance the post-war rise and evolution of public policy research. Here Peter made important contributions.

In 1984, Peter gracefully gave me an opportunity to explain these developments in an article on the subsequent development of policy analysis in Germany. Essential to these developments was Peter's own efforts to usher in this transfer and "travel" of concepts. In all ways, Peter DeLeon played an outstanding role as a dignified heir and eloquent advocate of the "policy sciences" legacy and message.

deLeon, P. (1991). Political Events and the Policy Sciences. In P. Wagner, C. Hirschon Weiss, B. Wittrock \& H. Wollmann (Eds.), Social Sciences and Modern States (pp. 86-109). Cambridge: Cambridge University Press.

Wagner, P., \& Wollmann, H. (1991). Beyond Serving State and Bureaucacy: Problem Oriented Social Science in Germany. Knowledge and Policy, 4(1-2), 56-88.

Wittrock, B., Wagner, P., \& Wollmann, H. (1991). The Policy Orientation: Legacy and Promise. In P. Wagner, C. Hirschon Weiss, B. Wittrock \& H. Wollmann (Eds.), Social Sciences and Modern States (pp. 2-27). Cambridge: Cambridge University Press.

Wittrock, B., Wagner, P., \& Wollmann, H. (1991). Social Science and the Modern State: Policy Knowledge and Political Institutions in Western Europe and the United States. In P. Wagner, C. Hirschon Weiss, B. Wittrock \& H. Wollmann (Eds.), Social Sciences and Modern States (pp. 28-85). Cambridge: Cambridge University Press.

Wollmann, H. (1984), Policy Analysis: Some observations on the West German Scene. Policy Sciences, 17, 27-47.

Wollmann, H. (2010). Soziologie Zwischen Kaiserreich, Weimarer Republik und NS- Regime. In H-E. Tenorth (Ed.), Geschichte der Universität unter den Linden Berlin, vol. 3, Akademie-Verlag, in Spanish translation: Wollmann, H. (2014). Surgimiento y Ruptura de la Sociología Alemana. Entre el Imperio, la República y el régimen Nazi. Revista Barataria, 18, 29-43. 